\title{
A STUDY ON THE VARIABLES PREDICTING READING COMPREHENSION
}

\author{
Mustafa BAŞARAN \\ Doç. Dr., Yıldız Teknik Üniversitesi, Eğitim Fakültesi, Temel Eğitim Bölümü, mbasaran66(at)yahoo.com, ORCID: 0000-0003-1684-5852
}

Başaran, Mustafa. "Reading Comprehension and Attitude towards Reading, Structure of the Text, Reading Speed and Preliminary Information”. ulakbilge, 60 (2021 May1s): s. 647-658. doi: 10.7816/ulakbilge-09-60-01

\begin{abstract}
The correlational survey design was used in this study in order to determine whether the attitude towards reading, text type and text subject, reading speed, correct reading, lack of prior knowledge and the amount of change in the surface structure of the text predict students' literal and deep reading comprehension skills. The study group of the research study is 180 students selected from amongst grade 4 students attending public primary schools in Esenler and Zeytinburnu districts of Istanbul province in the fall semester of the 2019-2020 academic year. According to the results of the regression analysis conducted in the study, the relative importance order of the variables that predict not being able to make deep meaning (meaning in depth of text) are the inability to make literal meaning, attitude towards reading, change in the superficial structure, attitude towards the subject, correct reading, attitude towards the narrative text, reading speed and pre-learning. Together, these factors explain $42 \%$ of not being able make deep meaning. The order of relative importance of the variables predicting the inability to construct literal meaning is make deep meaning, change in the superficial structure, attitude towards reading, correct reading, pre-learning, attitude towards the narrative text, attitude towards the subject and reading speed. Together, these factors explain $33 \%$ of not being able to make literal meaning.
\end{abstract}

Keywords: reading comprehension and reading attitude, reading comprehension and structure of texts, reading comprehension and reading speed, reading comprehension and preliminary information 


\section{Introduction}

With the effect of behaviourism, which was the dominant paradigm of the period until the 1950s, reading was defined as "vocalizing written symbols". As a result of this approach, teachers focused on teaching the characteristics of the alphabet, introducing written symbols and vocalizing them correctly. However, this understanding has changed with the observation that individuals who read the same text but make different meanings. Especially after the 1950s, with the effect of the cognitive approach, the process of placing knowledge in the mind has gained importance. After this paradigm change, the researchers focused on factors such as intelligence, attention, perception, etc. those are effective in the reading process (Akyol, 2014). However, the cognitive approach and the indirect result of this approach, the "Generative-Transformational Language Model", were able to explain how language exists in the mind and how reading takes place as a process. That said, it could not provide satisfactory answers to the questions of how meaning is constructed in reading and how reading teaching can be more effective. In recent years, constructivism, an approach that explains better how reading takes place and how meaning is constructed, is accepted by field educators. According to this approach, reading can be defined as "the process in which the information that reaches cognition as a result of a process that consists of perception, attention, memory, etc. obtained by vocalizing written symbols and controlled by executive cognition, is associated with prior knowledge by using mental skills (sorting, classification, problem solving, inferencing, etc.) and new information is built in the mind" (Başaran, 2013). In other words, reading is reaching new meanings as a result of interaction with the author and writing a new text based on a text. According to this approach, the ultimate aim of reading education is to teach understanding. In this process, vocalizing is a means, not a goal (Abadiano \& Turner, 2005; Guthrie \& Wigfield, 2000; Güneş, 2007; Paris et al., 2005; Snow, 2002).

In the realization of reading, there are more than 30 skills such as using the alphabet knowledge, grammar, vocabulary, understanding the sound-letter relationship, understanding the mechanical functioning of reading, seeing, perceiving, interpreting, evaluating, classifying, ordering, etc., skilfully using the cognitive skills, associating the information obtained from the text with their prior knowledge (Taylor, 2011). Indeed, looking at the studies on reading comprehension, it is evident that due to the multidimensional-complex structure of reading, researchers consider reading comprehension as the dependent variable, one or more of the skills related to reading as an independent variable and model their studies. In this study, the effects of the following factors were investigated: Superficial structural features of the text, correct reading, reading speed, necessary preliminary information to understand the text and attitude towards reading, text type and text topic (Cain, Oakhill, \& Bryant, 2004; Lai, Benjamin, Schwanenflugel, \& Kuhn, 2014; Oakhill, Cain \& Elbro, 2015; Snow, 2002).

The macro (type of text) and micro (cohesion elements, paragraph order, subject order, etc.) structure of a text can affect reading comprehension. Although the meanings (deep structures) of different texts are the same, the differences in their superficial structures may affect the reader's understanding of these texts (Durukan, 2014). Because there are many text types according to the narrative features. When the reader is confronted with the text structures that he/she is familiar with, he/she can understand the text better since he/she uses the diagrams related to these texts. However, the reader misunderstands the texts that he/she is unfamiliar with or have a narrative style either because they analyse them using their old schemas or they understand it more slowly because they try to develop new schemes for the new text (Crosley, Allen, \& Mcnamara, 2012; İskender \& Yiğit, 2015; Maxvell, 2011). This view is also the basis of the studies of simplifying (facilitating) the texts and vice versa. For example, in simplification, the macro or micro structure of the text is changed superficially (changing the location of sentences, breaking down or combining sentences, converting active sentences into passive structures, replacing words with synonyms, etc.) while maintaining the deep structure (meaning of the text) (Alamargot \& Chanquoy, 2001).

Another factor that has the potential to affect reading comprehension is correct reading and reading speed. Correct reading is the correct pronunciation of the written symbols in the text and is also the basis of correct understanding. This skill requires understanding the principles of the alphabet, understanding phonemes, having a wide vocabulary, finding and using the clues given in the text to predict the next word (Allington, 2006; Fuchs, et al., 2009; Klauda \& Guthrie, 2008; Rasinski, 2004).

Reading at the right speed is about the automatization of reading. Reading the words with a little mental effort and attention while reading is an indication that reading has become automatic. Automatization is also an extremely important skill for reading comprehension because when the reader reads words automatically, they can use all their mental energy for reading comprehension. In the absence of automatization, the reader will read the text intermittently, so he/she cannot see the meaning units and cannot understand the meaning relationships within or between sentences (Bashir \& Hook, 2009; Hasbrouck \& Tindal, 2006; Samuels, 2006).

In constructing the meaning, the reader's attitudes towards reading, the text type and the subject of the text are as effective as the text features and reading skills. Attitude can be defined as affective readiness that occurs as a result 
of experiences and has a directing effect on the individual's emotions and behaviours (Tavşanc1l, 2002). The attitude towards reading, the text type and the subject of the text are all feelings of the individual and may affect the reading time, the amount of text read, the level of reading comprehension and the reader's mental readiness (Kush, Marley, \& Brookhart, 2005). Individuals with high positive attitudes towards reading can read longer and more efficiently as their curiosity and interest will be high during the reading process. The attitude towards reading can be affected by the individual's personal characteristics (curiosity, self-efficacy, motivation, etc.), the socio-economic status of the family (the number and quality of magazines, newspapers, books taken to the home/classroom, the education level of the parents), and environmental factors (the teacher's attitude towards reading and applications etc.). However, according to the models developed as a result of the researches, the attitude towards reading is also affected by the type of text and the subject of the text (Çetin \& Karaata, 2010; Kocaarslan, 2016).

Another important factor affecting reading comprehension is preliminary information. According to the behavioural/positivist paradigm, the truth is objective, outside of the person and is discovered. However, according to the constructivist approach, knowledge is subjective, not discovered. The individual interprets new knowledge, prior knowledge and cognitive skills and reaches new meanings (Kılıç, 2001; Yurdakul, 2005). According to this approach, the knowledge acquired beforehand can make it easier and harder to make sense of what they read. It can also shape what they read. Because the information in mind is formed as a result of structuring new information based on previously learned knowledge (Saban, 2000). Considering that reading is also a way of acquiring knowledge, it is evident that prior knowledge of the reader about the subject and expression elements described in the text will affect the process of constructing meaning from the text. If the reader does not have enough prior knowledge about the subject described in the text or has incorrect prior knowledge, it will not be possible to understand the message the author wants to give through the text (Güneş, 2007; Akyol, 2014).

\section{Purpose of the Study}

The aim of this study is to determine the attitude towards reading, the text type and the text subject, reading speed, correct reading, prior knowledge and structure of the text that predicts the inability to make deep and literal meaning.

\section{Method}

In this study, relational scanning, which is one of the quantitative research methods, was used. In this design, the existence and degree of the relationship between multiple situations are examined without external intervention (Creswell, 2011).

\section{Sample}

In the research, grade 4 students attending public primary schools in Esenler and Zeytinburnu districts of Istanbul province in the fall semester of the 2019-2020 academic year were determined as the study population. The study group was determined using cluster sampling, one of the random sampling methods. In cluster sampling, not the elements from the population, but the clusters formed by the elements are selected (Creswell, 2011). In the study, one state school in Esenler and Zeytinburnu districts and six of the 10 fourth grade branches in these two schools were randomly selected. The classroom teachers of these selected classes were interviewed and a total of 195 students (97 girls and 98 boys) who were continuing their education in these classes were included in the sample, and "IFARCN" (Inventory of Factors Affecting Reading Comprehension Negatively) was applied to these students. After this application, in line with the opinions of the teachers, mainstreaming students, children of immigrant families and 15 students with special learning difficulties were excluded from the sample.

\section{Measurement Tools}

In the study, "Inventory of Factors Affecting Reading Comprehension Negatively" (IFARCN) was used to determine the relationship between the factors that negatively affect reading and reading comprehension. The inventory consists of eight parts:

In the first part of the inventory, some changes were made in the surface structure of the text named "Tailor and Old Man" based on the revision taxonomy developed by Faigley and Witte (1981) in order to determine the relationship between the surface structure of the text and the reading comprehension. These changes are "formal" and "preserving meaning" (Alamargot \& Chanquoy, 2001). The changes made are shown in Table 1. With these changes in the superficial structure, three texts were created that are the same in terms of subject, auxiliary ideas and main idea, but different in terms of superficial structure. It was decided that these three revised texts were the same with the original text in terms of subject, main idea and supplementary ideas, by taking the opinions of a total of three experts, two of 
whom completed their doctorate in the field of Turkish education and one who completed his/her doctorate in the field of classroom education. The changes made are:

Table 1. Changes in Superficial Structure and Number of Changes

\begin{tabular}{|c|c|c|c|}
\hline \multirow{2}{*}{ Changes Made } & \multicolumn{3}{|c|}{ Number of changes } \\
\hline & $1^{\text {st }}$. text & $2^{\text {nd }} \cdot$ text & $3^{\text {rd }}$. text \\
\hline Replacing words with unfamiliar words that have synonyms & 1 & 2 & 3 \\
\hline Breaking down units of meaning & 1 & 2 & 3 \\
\hline Converting straight sentences to transpose sentences & 1 & 2 & 3 \\
\hline Converting active sentences into passive voice sentences & 1 & 2 & 3 \\
\hline Replacing a sentence within a paragraph & 1 & 2 & 3 \\
\hline Lengthening sentences by combining & 1 & 2 & 3 \\
\hline Replacing words in a sentence & 1 & 2 & 3 \\
\hline Total & 7 & 14 & 21 \\
\hline
\end{tabular}

In the second part of the inventory, questions related to three different texts (Tailor and Old Man), whose superficial structure was changed by making changes in the surface structure at the same time, were used to determine the students' level of reading comprehension. In order to determine the students' level of constructing literal meaning (clearly expressed in the text, requiring the use of low-level cognitive skills, which can be measured with questions based on recall and recognition), 12 gap-filled questions with answers of one or a few words with clear answers in the text were prepared. Scoring was done by giving 0 points for incorrect answers, 1 point for partially correct answers and 2 points for completely correct answers. Five open-ended questions were used to measure students' in deep meaningmaking skills (which can be measured with questions that are not explicitly stated/implied in the text, about finding relationships in the text or inter-text, requiring high-level mental skills). While scoring, scores between 0 and 5 were given from wrong answers to correct answers. The validity of these questions was ensured by taking the opinions of three experts, two of whom completed their doctorate in the field of Turkish education and one who completed his/her doctorate in classroom education. The answers were evaluated by two Turkish teaching experts and the students were awarded the points reached as a result of the joint decision of these experts.

In the third part of the inventory, a Likert type triple rating scale consisting of 13 items developed by Başaran and Ateş (2009) was used to determine students' attitudes towards reading. Content validity of the scale was ensured by obtaining the opinions of three field experts. Factor analysis was made for structural validity. In this analysis, a single factor that explains $47.37 \%$ of the total variance emerged and it was observed that the factor loads of all 13 items were more than .30. In the test conducted to ensure the reliability of the scale, the Cronbach's alpha coefficient was found to be .76 .

In the fourth part of the inventory, a Likert-type triple rating scale consisting of 13 items was used to determine the students' attitudes towards the subject of the story named "Tailor and Old Man" used in the study. Content validity of the scale was ensured by obtaining the opinions of three field experts. Factor analysis was performed for the structural validity of the scale. In this analysis, a single factor that explains $55.27 \%$ of the total variance emerged and it was observed that the factor loads of all 13 items were more than 30 . In the test conducted to ensure the reliability of the scale, the Cronbach's alpha coefficient was found to be .72 .

In the fifth part of the inventory, a 10-item Likert-type triple rating scale developed by the researcher was used to determine students' attitudes towards narrative texts. Content validity of the scale was ensured by obtaining the opinions of three field experts. Factor analysis was made for structural validity. In this analysis, a single factor that explains $67.57 \%$ of the total variance emerged and it was determined that the factor loads of all 10 items were more than 30. In the test conducted to ensure the reliability of the scale, the Cronbach Alpha coefficient was found to be 89. In the sixth part of the inventory, a measurement tool based on the word discrimination technique (Price, et al., 2012; Price, et al., 2016) was used to determine students' correct reading skills during silent reading. While developing this tool, the spaces between words and punctuation marks in the selected text (Pole Express) were deleted and all words were written in capital letters. The students were asked to separate the words in the text by drawing lines within three minutes. The words that the students separated correctly were counted as the words they read correctly.

In the seventh part of the inventory, a text (Under Our Flag) consisting of 353 words and 1020 letter characters was read in order to determine the silent reading speed of the students. Thesampled students read the text silently and one minute later the students were asked to mark the place where they stopped. The silently reading speed of the students was calculated using these data.

In the eighth and last part of the inventory, the measurement tool developed to determine the effect of lack of prior knowledge on reading comprehension was used. In this measurement tool, technical terms related to the work 
(tailoring) of those in the text (Tailor and Old Man) selected to measure reading comprehension and the meanings of idioms and proverbs used to describe the moods of those were asked. The questions were open-ended and it was decided that the students who wrote the synonym or definition of the words correctly knew the meaning of the relevant word, idiom or proverb.

\section{Procedure}

The research was carried out under the supervision of the researcher in the classroom and by classroom teachers. Two public schools in Esenler and Zeytinburnu districts of Istanbul were determined, the grade 4 classroom teachers at these schools were interviewed. The purpose and method of the study were explained to the teachers. The teachers were provided information on applying IFARCN in their classes on a voluntary basis. In order for the correlation and regression analyses to be made after the application of the inventory to be easier to interpret and understand, the scores for inability to make in-depth and surface meaning were calculated by subtracting the student's score from the relevant test from the maximum score that could be obtained from the relevant test. The quantitative data obtained after these applications were analysed using the SPSS 25.0 software. Data sets were subjected to normality tests (kurtosis and skewness) to decide whether parametric or non-parametric tests would be used in the analysis of the data, although the sample size was 180. In order to determine the relationship between the independent variables of the research and the reading comprehension, and also to determine whether there is a case of multiple linearity between these variables correlation (Pearson Moments Multiplication Correlation Coefficient-r) was used and Regression was used to test the predictive status of not being able to make deep meaning (meaning in depth of text) and not to make literal meaning.

\section{Findings}

The findings obtained as a result of the applications in this section are given in tables and interpreted.

Table 2. Normality Test Regarding the Scores for Inability to Make Deep Meaning and Inability to Make Literal Meaning Attitude Regarding the Narrative Text, Attitude Regarding the Subject, Attitude Regarding Reading, Reading Speed, Correct Reading and Having Prior Knowledge

\begin{tabular}{|c|c|c|}
\hline Score type & Tests & Coefficient \\
\hline \multirow{2}{*}{ Inability To Make Deep Meaning } & Skewness & -.161 \\
\hline & Kurtosis & -.515 \\
\hline \multirow{2}{*}{ Inability To Make Literal Meaning } & Skewness & .371 \\
\hline & Kurtosis & -.073 \\
\hline \multirow{2}{*}{ Attitude Regarding The Narrative Text } & Skewness &, 045 \\
\hline & Kurtosis & -.625 \\
\hline \multirow{2}{*}{ Attitude Regarding The Plot } & Skewness & -.029 \\
\hline & Kurtosis & -.830 \\
\hline \multirow{2}{*}{ Attitude Regarding Reading } & Skewness & ,493 \\
\hline & Kurtosis &, 172 \\
\hline \multirow{2}{*}{ Reading Speed } & Skewness & -.371 \\
\hline & Kurtosis &, 551 \\
\hline \multirow{2}{*}{ Correct Reading } & Skewness & -.664 \\
\hline & Kurtosis & 1.459 \\
\hline \multirow{2}{*}{ Having Prior Knowledge } & Skewness & -.262 \\
\hline & Kurtosis & -.511 \\
\hline
\end{tabular}

In Table 2, the skewness and kurtosis values regarding the scores of inability to make deep meaning, inability to make literal meaning, attitude regarding the narrative text, attitude regarding the subject, attitude regarding reading, reading speed, correct reading and having prior knowledge are given. When these values are examined, it is seen that the skewness and kurtosis coefficients for all score distributions vary between -.830 and +1.459 . Since the coefficient of skewness and kurtosis should be between +1.5 and -1.5 in order to decide that the scores obtained in social sciences show normal distribution characteristic (Tabachnick \& Fidell, 2007), it can be said that the scores used in the study have normal distribution characteristics.

In Table 3, the inability to make deep meaning and the inability to make literal meaning and the amount of change in the surface structure that may affect them, correct reading, reading speed, amount of prior knowledge, the attitude towards reading, the subject and the narrative text can be seen. According to the table, there is a strong positive correlation between the inability to make deep meaning and the inability to make literal meaning $(r=.474$ and $p>.01)$. In addition, there is a positive relationship between the inability to make deep meaning and the change in the surface structure, and there is a significant negative relationship between correct reading, reading speed, amount of prior 
knowledge, and attitude regarding reading, the subject and the narrative text $(r=.396$ and $p>.01$ between inability to make deep meaning and superficial structure; attitude regarding reading $r=-.192$ and $\mathrm{p}>.01$; attitude regarding the subject $\mathrm{r}=-.281$ and $\mathrm{p}>.01$; attitude regarding the narrative text $\mathrm{r}=-.280$ and $\mathrm{p}>.01$; correct reading $\mathrm{r}=-.279$ and $\mathrm{p}>$ .01 and $\mathrm{p}>.05$; having prior knowledge $\mathrm{r}=-.230$ and $\mathrm{p}>.01$ ). There is a positive correlation between inability to make literal meaning and change in the superficial structure, and there is a significant negative correlation between correct reading, amount of prior knowledge, and attitude towards reading, the subject and the narrative text. The relationship between reading speed and not being able to form literal meaning is not statistically significant. $(r=.273$ and $p>.01$ between inability to make literal meaning and superficial construct; attitude regarding reading $r=-.268$ and $\mathrm{p}>.01$; attitude regarding subject $r=-.447$ and $\mathrm{p}>.01$; the attitude regarding the narrative text $\mathrm{r}=-.373$ and $\mathrm{p}>.01$; correct reading $\mathrm{r}=-.396$ and $\mathrm{p}>.01$; reading speed $\mathrm{r}=-.161$ and $\mathrm{p}>.05$; having prior knowledge $\mathrm{r}=-.298$ and $\mathrm{p}>.01$ ). When looking at the relationship between the factors affecting reading, it is seen that there is a significant positive relationship (p> .05) between attitude towards reading and attitude towards the subject and correct reading, between the attitude towards the subject and the attitude towards the narrative text, correct reading and having prior knowledge, between the attitude towards the narrative text and the correct reading, between having prior knowledge and correct reading and reading speed, and lastly, between correct reading and reading speed. These findings can be interpreted as that there is a strong correlation between not being able to make meaning in-depth and not being able to make literal meaning. And there is also a significant relationship between the not being able to make meaning in-depth and the amount of change in the surface structure, correct reading, reading speed, amount of prior knowledge, attitude towards reading, the subject and the narrative text. There is a relationship between the inability to make literal meaning and the amount of change in the superficial structure, the amount of correct reading, the amount of prior knowledge, the attitude towards reading, the subject and the narrative text. Speed of reading has relatively little effect on inability to understand in depth. And finally there is no significant effect on inability to make literal meaning. When the table is examined, it is clear that all of the correlation coefficients of independent variables among themselves are lower than .70. When these findings are evaluated in terms of multiple regression analysis, it can be interpreted that there is no multi-linearity problem among independent variables.

Table 3. The Relationship between the Factors Affecting Reading Comprehension with Each Other, Inability to Make deep Meaning and the Inability to Make literal Meaning

\begin{tabular}{|c|c|c|c|c|c|c|c|c|}
\hline & $\begin{array}{l}\text { Inability to } \\
\text { Make Deep } \\
\text { Meaning }\end{array}$ & $\begin{array}{l}\text { Inability to } \\
\text { Make Literal } \\
\text { Meaning }\end{array}$ & $\begin{array}{l}\text { Chan. in } \\
\text { Literal } \\
\text { structure }\end{array}$ & $\begin{array}{l}\text { Attitude } \\
\text { regarding } \\
\text { Reading }\end{array}$ & $\begin{array}{l}\text { Attitude } \\
\text { Regarding } \\
\text { the Plot }\end{array}$ & $\begin{array}{l}\text { Attitude } \\
\text { Regarding } \\
\text { the Narrativ } \\
\text { Text }\end{array}$ & $\begin{array}{r}\text { Correct } \\
\text { ereading }\end{array}$ & $\begin{array}{l}\text { Reading } \\
\text { speed }\end{array}$ \\
\hline Inability to Make deep Meaning & 1 & & & & & & & \\
\hline Inability to Make Literal Meaning & $.474^{* *}$ & 1 & & & & & & \\
\hline Change in superficial structure & $.273^{* *}$ & $.396^{* *}$ & 1 & & & & & \\
\hline Attitude regarding Reading & $-.268^{* *}$ & $-.192^{* *}$ & .096 & 1 & & & & \\
\hline Attitude Regarding the Plot & $-.447^{* *}$ & $-.281^{* * *}$ & -.039 & $.176^{*}$ & 1 & & & \\
\hline Attitude Regarding the Narrative Text & $-.373^{* *}$ & $-.280^{* * *}$ & -.018 & .109 & $.396^{* *}$ & 1 & & \\
\hline Correct reading & $-.396^{* *}$ & $-.279^{* *}$ & -.032 & $.308^{* * *}$ & $.364^{* *}$ & $.217^{* *}$ & 1 & \\
\hline Reading speed & $-.161^{*}$ & -.015 & .118 & .003 & .065 & .103 & $.151^{*}$ & 1 \\
\hline Having prior knowledge & $-.289^{* *}$ & $-.230^{* *}$ & .032 & .012 & $.338^{* *}$ & $.188^{*}$ & $.231^{* *}$ & $.155^{*}$ \\
\hline
\end{tabular}

When the binary correlation results in Table 4 are examined, it is seen that there is a positive and significant relationship between not being able to understand meaning in depth and not being able to theorize literal meaning and the change in the surface structure of the text and there is a significant negative relationship between reading accuracy, reading speed, amount of prior knowledge, and attitude towards reading, the subject and the narrative text. When the standardized regression coefficients are examined, the relative importance order of the independent variables considered on inability to make meaning in-depth is inability to make the literal meaning, the attitude towards reading, the change in the superficial structure, the attitude towards the subject, the correct reading, the attitude towards the narrative text, the speed of reading and having prior knowledge. Together, these factors explain $42 \%\left(\mathrm{R}=, 666\right.$ and $\mathrm{R}^{2}$ $=, 418$ ) of inability to make meaning in-depth. 
Table 4. Status the Factors that Affecting Reading Comprehension to Make Meaning In-Depth

\begin{tabular}{|c|c|c|c|c|c|c|c|c|}
\hline $\begin{array}{l}\text { Dependent } \\
\text { Variable }\end{array}$ & Independent Variables & $\mathbf{B}$ & $\begin{array}{l}\text { Stan. } \\
\text { Fault }\end{array}$ & $\boldsymbol{\beta}$ & $\mathbf{t}$ & $\mathbf{p}$ & $\underset{\mathbf{r}}{\operatorname{Binary}}$ & $\begin{array}{l}\text { Partial } \\
\quad \mathbf{r}\end{array}$ \\
\hline \multirow{9}{*}{$\begin{array}{l}\text { Inability to } \\
\text { make meaning } \\
\text { in-depth }\end{array}$} & Constant & 32.99 & 4.761 & & 6.930 & .000 & & \\
\hline & $\begin{array}{l}\text { Inability To Make Literal } \\
\text { Meaning }\end{array}$ & .331 & .117 & .197 & 2.824 & .005 & .474 & .211 \\
\hline & $\begin{array}{l}\text { Change In Superficial } \\
\text { Structure }\end{array}$ & .138 & .042 & .211 & 3.275 & .001 & .273 & .243 \\
\hline & Attitude Regarding Reading & -.229 & .093 & -.153 & 2.472 & .014 & -.268 & -.186 \\
\hline & Attitude Regarding The Plot & -.108 & .036 & -.203 & 2.981 & .003 & -.447 & -.222 \\
\hline & $\begin{array}{l}\text { Attitude Regarding The } \\
\text { Narrative Text }\end{array}$ & -.061 & .025 & -.156 & 2.450 & .015 & -.373 & -.184 \\
\hline & Correct Reading & -.105 & .050 & -.138 & 2.113 & .036 & -.396 & -.160 \\
\hline & Reading Speed & -.053 & .027 & -.117 & 1.990 & .048 & -.161 & -.150 \\
\hline & Having Prior Knowledge & -.044 & .028 & -.101 & 1.603 & .111 & -.289 & -.122 \\
\hline
\end{tabular}

Inability to make deep meaning $=32.99$ Constant + inability to make literal meaning. $331+$ attitude towards reading $-.229+$ amount of change in surface structure -. $138+$ attitude towards subject -. $108+$ correct reading - $105+$ attitude towards narrative text -. 061 + reading speed $-.053+$ amount of pre-information -.044

Table 5. Status the Factors that Affecting Reading Comprehension to Make Literal Meaning

\begin{tabular}{llccccccc}
\hline $\begin{array}{c}\text { Dependent } \\
\text { Variable }\end{array}$ & \multicolumn{1}{c}{ Independent Variables } & B & $\begin{array}{c}\text { Stan. } \\
\text { Fault }\end{array}$ & $\boldsymbol{\beta}$ & $\mathbf{t}$ & $\begin{array}{c}\text { p } \\
\text { Inability to }\end{array}$ & $\begin{array}{c}\text { Binary } \\
\mathbf{r}\end{array}$ & $\begin{array}{c}\text { Partial } \\
\mathbf{r}\end{array}$ \\
Make Literal & $\begin{array}{l}\text { Inability to make meaning in- } \\
\text { Meaning }\end{array}$ & .135 & .048 & .226 & 2.824 & .005 & .474 & .211 \\
& depth & & & & & & & \\
& Change in superficial structure & .132 & .026 & .341 & 5.120 & .000 & .396 & .365 \\
& Attitude regarding Reading & -.107 & .060 & -.120 & 1.795 & .074 & -.192 & -.136 \\
& Attitude Regarding the Plot & -.008 & .024 & -.024 & .320 & .750 & -.281 & -.024 \\
& Attitude Regarding the Narrative & -.030 & .016 & -.128 & 1.865 & .064 & -.280 & -.141 \\
& Text & & & & & & & \\
& Correct reading & -.036 & .032 & -.080 & 1.131 & .260 & -.279 & -.086 \\
& Reading speed & -.008 & .017 & -.029 & .447 & .655 & -.015 & .034 \\
& Having prior knowledge & -.033 & .017 & -.128 & 1.897 & .059 & -.230 & -.144 \\
\hline
\end{tabular}

Inability to make literal meaning $=9.751$ Constant + inability to make deep meaning. $135+$ amount of change in superficial structure -. $132+$ attitude towards reading -. $107+$ correct reading -. $036+$ amount of prior knowledge -. $033+$ attitude towards narrative text $-.030+$ attitude to the subject $-.008+$ reading speed -.008

When the binary correlation results in Table 5 are examined, it is seen that there is a positive relationship between inability to make literal meaning, inability to make meaning in-depth and the change in surface structure and there is a significant negative correlation between the correct reading, the amount of prior knowledge, and the attitude towards reading, the subject and the narrative text and there is a much lower negative correlation from reading speed. When the standardized regression coefficients are examined, the relative importance order of the independent variables on the inability to make literal meaning is inability to make meaning in-depth, change in the superficial structure, attitude towards reading, correct reading, having prior knowledge, attitude towards the narrative text, attitude towards the subject, and reading speed. Inability to make deep meaning, amount of change in surface structure, correct reading, reading speed, amount of prior knowledge, attitude towards reading, topic and narrative text explain 33\% ( $\mathrm{R}=, 599$ and $\mathrm{R}^{2}=$, 329) of inability to make literal meaning.

\section{Discussion}

According to the results of the regression analysis conducted in the study, the relative importance order of the variables that predict not being able to make deep meaning are the inability to think literal meaning, attitude towards reading, change in the superficial structure, attitude towards the subject, correct reading, attitude towards the narrative text, reading speed and pre-learning. Together, these factors explain $42 \%$ of not being able make meaning in depth. The order of relative importance of the variables predicting the inability to construct superficial meaning is make meaning 
in depth, change in the superficial structure, attitude towards reading, correct reading, pre-learning, attitude towards the narrative text, attitude towards the subject and reading speed. Together, these factors explain $33 \%$ of not being able to make literal meaning.

According to the results of the study, there is a strong positive relationship between inability to make meaning in-depth and inability to make literal meaning. In the regression analysis, it was seen that the strongest variable that predicted fourth grade students' inability to make deep meaning was inability to make literal meaning. Based on these findings, it can be stated that it is also difficult for students who do not understand or remember the information clearly expressed in the text to find/remember the information implied in the text. The results of the study conducted by Başaran (2013) also support this result: In this study, it was concluded that there was a strong relationship between the scores of fourth grade students in the deep meaning making test and the scores they got from the test measuring literal meaning.

There is a strong negative relationship between the inability to make meaning both deeply and superficially and motivational factors. This result coincides with the results of many studies in this field (Balcı, Uyar \& Büyükikiz, 2012; Baş \& Şahin, 2012; Garrett, 2002; Gür-Erdoğan \& Demir, 2016; İşeri, 2010; Özdemir \& Şerbetçi, 2018; Yalınkılıç, 2007; Yılmaz \& Benli, 2010). According to the results of the research, the subject of the most read text, the type of the text and the attitude towards reading, in turn, affect the reading comprehension. When this finding is considered together with the results of the researches showing that there is a significant relationship between the text type and the text subject and reading comprehension, it can be said that the attitudes of the students lie behind the strong effect of the text type and subject on reading comprehension (Bayraktar, 2017; Başaran, 2007; Çakıcı, 2005; Karabay \& Kayıran, 2009; Karahan \& Taşdan, 2016; Sallabaş, 2008; Şeflek-Kovacıŏglu, 2006). The least influential motivational factor is the attitude towards reading. However, it should be taken into consideration that a narrative text was used in the study and the relationship between attitude towards narrative texts and attitude towards reading is low. Because although primary school students' attitudes towards reading are low, their attitudes towards narrative texts are generally high (Başaran \& Akyol, 2009; Başaran, 2007). In other words, when an informative text is in question, the level of the relationship between the attitude towards reading and making deep meaning can increase.

Another variable that negatively affects the deep meaning making is the superficial structure features of the text. The unnecessary lengthening of the sentences in the text, the preference of synonyms less used in daily life, the fragmentation of the meaning units in the sentence, the fragmentation of the sentences into the paragraph, the use of passive voice, the use of inverted sentences, etc., negatively affect the students' deep and literal meaning making. However, in the study, it was observed that there was no significant relationship between the number of changes in the surface structure of the text and reading speed and correct reading. In other words, since the change in the superficial structure does not affect the reading speed and correct reading, the decrease in students' reading comprehension is mostly related to the change in the superficial structure of the text (making the text difficult). This finding can be interpreted as the students are using the schemas they already have while reading the words, sentences and text structures that they are accustomed to (Crosley, Allen, \& Mcnamara, 2012; Maxvell, 2011; McLaughlin, 2012;) and they use their mental energy not to analyze the text but to understand what they are reading, so they both make more meaning from the text and remember more details.

There is also a negative relationship between reading correctly and not being able to make deep and literal meaning. There may be two reasons for this phenomenon: If the student has difficulty establishing a letter-sound relationship, if he/she has not learned the mechanical aspect of reading and the features of the alphabet, he/she may have problems seeing, understanding, and extracting information both on the surface of the text (explicitly given) and in other layers (implied, not explicitly given, based on inference) as he will focus his attention on correct pronunciation and not on understanding. The second reason is that wrong vocalization causes misunderstanding (Güneş, 2007; Akyol, 2014).

Lack of prior knowledge is also effective on both in-depth and literal meaning. According to the constructivist approach, the (new) information taken from the text is made meaningful with preliminary information and new knowledge is constructed by using cognitive skills. In this case, it is expected that the lack of prior knowledge will negatively affect making meaning in depth (Güneş, 2009). The reason for the lack of prior knowledge to negatively affect the literal meaning formation can also be discussed with the qualitative findings of this study: According to the qualitative findings of the study, the students almost "get stuck" in the words they do not understand, etc., and continue to vocalize the text while trying to handle that part in their mind. For this reason, students may have problems understanding and remembering the information clearly stated in the parts of the text. In addition, according to the results of this study, there is a positive and significant relationship between correct and fast reading and preliminary information. This finding can be interpreted as that students focus their attention on the reading comprehension dimension when their prior knowledge is insufficient and when they have sufficient prior knowledge on the mechanical dimension of reading. 
In the study, a negative relationship, albeit at a low level, was observed between reading speed and inability to make deep meaning. However, it was observed that the relationship between reading speed and not being able to make literal meaning was not significant. This finding seems to contradict with the results of the research (Çetinkaya, Ülper, \& Yağmur, 2015; Saraçoğlu et al., 2011; Talada, 2007; Türkyılmaz et al., 2013; Yıldırım \& Ateş, 2012;) showing a relationship between reading speed and comprehension. However, it should not be forgotten that reading too fast as well as reading too slowly can negatively affect reading comprehension. The important thing is to be able to adjust the reading speed according to the type of text and the purpose of reading (Akyol, 2014). The reason for this low relationship between reading speed and reading comprehension in the study may be that students who read very fast also have trouble understanding what they read.

Based on all these findings, it can be suggested that classroom teachers give priority to the factors related to the text (the attitude of the student regarding the subject and type of the text, the readability of the text, etc.) in their studies about students who cannot understand what they read: Students prefer to read texts in which heroes resembling themselves, scenes resembling their surroundings or problems resembling their own problems are solved (Başaran, 2007). From this point of view, low motivation and negative attitude problems that cause inability to understand can be solved by choosing appropriate texts. In addition, when the texts are rearranged to make them suitable for students, the problems of incomprehension of what they read can be overcome.

In order to solve problems related to reading comprehension, emphasis should be given to studies that examine prior knowledge or stimulate it. Especially, studies on textual questions and vocabulary should be done in order to gain the preliminary information necessary to understand the text.

Research results show the importance of evaluating reading as a process, not as a result. Students who cannot understand what they read focus more on vocalizing and finishing the text correctly. When teachers follow their students' readings, they should pay attention not only to whether they vocalize correctly, but also whether they read prosodically. It also became clear that the skills discussed in the study were generally interrelated. For this reason, it may be suggested to teachers to discuss, evaluate and develop reading skills together. As a result of the study, it was concluded that motivational factors are important in reading comprehension, so when teachers see that a student has a problem in understanding, instead of prolonging the process and forcing the student, they should interrupt the process and prevent the student from being filled with negative emotions. Finally, since to make deep meaning and literal meaning are strong predictor of each other, teachers can do activities that improve both to make deep and literal meaning and ask meaning-making questions that require different cognitive processes such as comprehension, practice or analysis.

\section{References}

Abadiano, H. R. \& Turner, J. (2005). Central Connecticut State University Reading fluency: The road to developing efficient and effective readers. The NERA Journal, 41(1), 50-56.

Akyol, H. (2014). Türkçe Öğretimi. Ankara: PegemA.

Alamargot, D. \& Chonquoy, L. (2001). Through The Models of Writing. Londra: Kluwer Academic Publishers.

Allington, R. L. (2006). Fluency: Still waiting after all these years. S. J. Samuels \& A. E. Farstrup (Eds.), What research has to say about fluency instruction (pp. 94-105). Newark: International Reading Association.

Bacanlı, H. (2002). Gelişim ve Öğrenme. Ankara: Nobel Publishing.

Balcı, A., Uyar, Y. \& Büyükikiz, K. (2012). İlköğretim 6. sınıf öğrencilerinin okuma alışkanlıkları, kütüphane kullanma sıklıkları ve okumaya yönelik tutumlarının incelenmesi. Turkish Studies, 7(4), 965-985.

Bashir, A. S. \& Hook, P. E. (2009). Fluency: A key link between word identification and comprehension. Language, Speech, and Hearing Services in Schools, 40(2), 196-200.

Baş, G. \& Şahin, C. (2012). İlköğretim 6. 7. ve 8. sınıf öğrencilerinin okuma tutumları ve yazma eğilimleri ile Türkçe dersindeki akademik başarıları arasındaki ilişsi. Turkish Studies, 7(3), 555-572.

Başaran M. \& Akyol H. (2009). İlköğretim beşinci sınıfa devam eden öğrencilerin hikâye unsurlarına ilişkin beklentileri. Pamukkale Üniversitesi Sosyal Bilimler Enstitüsü Dergisi, 2(1), 226-251.

Başaran, M. \& Ateş, S. (2009). İlköğretim beşinci sınıf öğrencilerinin okumaya ilişkin tutumlarının incelenmesi. Gazi Üniversitesi Eğitim Fakültesi Dergisi, 29(1), 77-80.

Başaran, M. (2013). Okuduğunu anlamanın bir göstergesi olarak akıcı okuma. Kuram ve Uygulamada Eğitim Bilimleri, 13(4), 1303-0485.

Başaran, M. (2007). İlköğretim beşinci sınıf öğrencilerinin hikâye edici metinlere iliş̧kin tercihleri. Unpublished doctoral dissertation, Gazi Üniversitesi, Eğitim Bilimleri Enstitüsü, Ankara.

Bayraktar, İ. (2017). Ortaokul 7. sınıf öğrencilerinin okuma tutumları ile okuduğunu anlama becerileri arasındaki ilişki. International Journal of Languages' Education and Teaching, 5(4), 582-594. 
Butgel T. S., Gözü, Ö. \& Özen, G. (2016). Nitel ve nicel araştırma yöntemlerinin bir arada kullanılması karma araştırma yöntemi. Anadolu Üniversitesi İletişim Bilimleri Fakültesi Uluslararası Hakemli Dergisi, 24(2), 106112.

Cain, K., Oakhill, J. \& Bryant, P. (2004). Children's reading comprehension ability: Concurrent prediction by working memory, verbal ability, and component skills. Journal of Educational Psychology, 96(1), 31-42.

Creswell, J. W. (2011). Educational research: Planning, conducting, and evaluating quantitative and qualitative research (3. Ed.). USA: Pearson Education Inc.

Crossley, S. A., Allen, D. \& McNamara, D. (2012). Text simplification and comprehensible input: A case for an intuitive approach. Language Teaching Research, 16(1), 89-108.

Çakıcı, D. (2005). Ön örgütleyicilerin okumaya yönelik tutum ve okuduğunu anlama üzerindeki etkileri. unpublished doctoral dissertation. Dokuz Eylül Üniversitesi, Eğitim Bilimleri Enstitüsü, İzmir.

Çetin, Y. \& Karaata, C. (2010). Türk öğrencilerin okumama sorununa çözüm önerileri. Çukurova Üniversitesi Sosyal Bilimler Enstitüsü Dergisi, 19(1), 202-215.

Çetinkaya, G., Ülper, H. \& Yağmur, K. (2015). Öğrencilerin doğru ve akıcı sessiz sözcük okuma becerileriyle kavrama başarıları arasındaki ilişki, Illkögretim Online, 14(3), 993-1004.

Durukan, E. (2014). Metinlerin okunabilirlik düzeyleri ile öğrencilerin okuma becerileri arasındaki ilişki. Ana Dili Eğitimi Dergisi, 2(3), 68-76.

Engin, A. O., Aksakal, İ., Seven, M. A. \& Sayan, A. (2016) Öğrenme ve stres arasındaki iliş̧ki. Ekev Akademi Dergisi, 20(66), 107-128.

Erden, M., (2005). Gelişim ve Öğrenme. Ankara: Arkadaş Yayıncılık.

Faigley, L. \& Witte, S. (1981). Analyzing revision. College Composition and Communication, 32(4), 400-414.

Fuchs, L. S., Fuchs D., Hosp M. K. \& Jenkins J. R. (2009). Oral reading fluency as an indicator of reading competence: A theoretical, empirical, and historical analysis. Scientific Studies of Reading, 5(3), 239-256.

Garrett, J. E. (2002). Enhancing the attitudes of children toward reading: Implications for teachers and principals. Reading Improvement, 39(1), 21-24.

Guthrie, J. T. \& Wigfield, A. (2000). Engagement and motivation in reading. M. L. Kamil, P. B. Mosenthal, P. D. Pearson, \& R. Barr (Ed.), Handbook Of Reading Research, V. 3. (403-422). Londra: Lawrence Erlbaum Associates Publishers.

Güneş, F. (2009). Türkçe öğretiminde günümüz gelişmeleri ve yapılandırıcı yaklaşım. Mustafa Kemal Üniversitesi Sosyal Bilimler Enstitüsü Dergisi, 6(11), 1-21.

Güneş, F. (2007). Ses Temelli Cümle Yöntemi ve Zihinsel Yapılandırma. İstanbul: Nobel Yayınları.

Gür Erdoğan, D. \& Demir, Y. E. (2016). İlkokul dördüncü sınıf öğrencilerinin okumaya yönelik tutumlarının farklı değişkenler açısından incelenmesi. Sakarya Üniversitesi Eğitim Fakültesi Dergisi, 32, 85-96.

Hasbrouck, J. \& Tindal G. A. (2006). Oral reading fluency norms: A valuable assessment tool for reading teachers. The Reading Teacher, 59(7), 636-644.

İşeri, K. (2010). İlköğretim ikinci kademe öğrencilerinin okuma tutumlarının incelenmesi. Uluslararası İnsan Bilimleri Dergisi, 7(2). 468-487.

Karabay, A. \& Kuşdemir-Kayıran, B. (2010). İlköğretim beşinci sınıf öğrencilerinin okuduğunu anlama becerileri ve okumaya ilişkin tutumları arasındaki ilişki. Çukurova Üniversitesi Eğitim Fakültesi Dergisi, 3(38), 110-117.

Karahan, B. \& Taşdan M. (2016). 5. ve 6. sınıf öğrencilerinin okumaya karşı tutum ve motivasyonlarının okuduğunu anlama becerileri ile ilişkisi. Uluslararası Türkçe Edebiyat Kültür Eğitim Dergisi, 5(2), 949-969.

Kılıç, G. B. (2001). Oluşturmacı fen öğretimi. Kuram ve Uygulamada Eğitim Bilimleri Dergisi. 1(1), 7-22.

Klauda, S. L., \& Guthrie, J. T. (2008). Relationships of three components of reading fluency to reading comprehension. Journal of Educational Psychology, 100(2), 310-321.

Kocaarslan, M. (2016). An exploratory study of the relationships between reading comprehension competence, reading attitude and vividness of mental imagery among Turkish fourth-grade students. International Electronic Journal of Elementary Education, 8(4), 675-686.

Kush, J. C., Watkins, M. W. \& Brookhart, S. M. (2005). The temporal-interactive influence of reading achievement and reading attidute. Educational Research and Evaluation, 11(1), 30-42.

Lai, S. A., Benjamin, R. G., Schwanenflugel, P. J., \&Kuhn, M. R. (2014). The longitudinal relationship between reading fluency and reading comprehension skills in secondgrade children. Reading \& Writing Quarterly, 30(2), 116-138.

McLaughlin, M. (2012). Reading comprehension: What every teacher needs to know. The Reading Teacher, 65(7), $432-440$

Maxvell, S. (2011). The effects of two types of text modification on english language learners reading comprehension: Simplification versus elaboration. Minnesota: Hamline University. 
Noyan, A. (2000). Yaşamda ve Hekimlikte Fizyoloji. Ankara: Meteksan.

Oakhill, J., Cain, K. \& Elbro, C. (2015). Understanding and Teaching Reading Comprehension: A Handbook. New York: Routledge.

Özdemir, S. \& Şerbetçi, H. N. (2018). İlkokul Dördüncü Sınıf Öğrencilerinin Okumaya Yönelik Tutumları (Bartın Örneklemi). İlköğretim Online, 17(4), 2110-2123.

Paris, S. G., Carpenter, R. D., Paris, A. H. \& Hamilton, E. E. (2005). Spurious and Genuine Correlates of Children's Reading Comprehension. Center for improvement of early reading achievement. S. G. Paris \& S. A. Stahl (Ed.), Children's reading comprehension and assessment (131-160). Londra: Lawrence Erlbaum Associates Publishers.

Price, K. W., Meisinger, E. B., Louwerse, M. M. \& D’Mello, S. (2016). The contributions of oral and silent reading fluency to reading comprehension. Reading Psychology, 37(2), 167-201.

Price, K. W., Meisinger, E. B., Louwerse, M. M., \& D'Mello, S. K. (2012). Silent reading fluency using underlining: Evidence for an alternative method of assessment. Psychology in the Schools, 49(6), 606-618.

Rasinski, T. V. (2004). Assessing Reading Fluency. HI: Pacific Resources for Education and Learning.

Saban, A, (2000). Öğrenme-Öğretme Süreci: Yeni Teori ve Yaklaşımlar. Ankara: Nobel Yayınları.

Sallabaş, E. (2008). İlköğretim 8. sınıf öğrencilerinin okumaya yönelik tutumları ve okuduğunu anlama becerileri arasındaki ilişki. İnönü Üniversitesi Eğitim Fakültesi Dergisi, 9(16), 141-155.

Samuels, S. J. (2006). Toward a model of reading fluency. S. J. Samuels \& A. E. Farstrup (Ed.), What Research Has to Say about Fluency Instruction (pp. 24- 46). Newark: International Reading Association.

Saracaloğlu, A. S., Dedebali, N. C. \& Karasakaloğlu, N. (2011). Sekizinci sınıf öğrencilerinin sessiz okuma hıları ve okuduğunu anlama düzeyleri. Ahi Evran Üniversitesi Eğitim Fakültesi Dergisi, 12(3), 177-193.

Senemoğlu, N. (2007). Gelişim Öğrenme ve Öğretim (Kuramdan Uygulamaya), İstanbul: Gönül.

Snow, C. E. (2002). Reading For Understanding: Toward a Research and Development Program in Reading Comprehension. Santa Monica: RAND.

Şeflek Kovacıŏ̆lu, N. (2006). İlköğretim ikinci sınıflarında aile çevresi ve çocuğun okumaya karşı tutumu ile okuduğunu anlama becerisi arasindaki ilişsiler. Unpublished master's thesis, Yıldız Teknik Üniversitesi, Sosyal Bilimler Enstitüsü, İstanbul.

Tabachnick, B. G. \& Fidell, L. S. (2007). Using Multivariate Statistics. Boston: Pearson Education Inc.

Talada, J. A. (2007). The relationship between oral reading fluency and comprehension. Unpublished master's thesis, The Faculty of the School of Education, Liberty University.

Taylor, S. E. (2011). The dynamic activity of reading. S. E. Taylor (Ed.). Exploring silent reading fluency: Its nature and development (pp. 3-37). Springfield: Charles C. Thomas.

Tashakkori, A. \& Teddlie, C. (2003). The past and future of mixed methods research: From data tirangulation to mixed method model designs. A. Tashakkori \&C. Teddlie (Ed.), Handbook of Mixed Methods in Social and Behavioral Research (671-701). CA: Thousand Oaks.

Tavşancıl, E. (2002). Tutumların Ölçülmesi ve SPSS ile Veri Analizi. Ankara: Nobel Yayınları.

Türkyılmaz, M., Can, R., Yıldırım, K. \& Ateş, S. (2014). Relations among oral reading fluency, silent reading fluency, retell fluency, and reading comprehension. ProcediaSocial and Behavioral Sciences, 116, 4030-4034.

Yıldırım, K. \& Ateş, S. (2012). Silent and oral reading fluency: Which one is the best predictor of reading comprehension of Turkish elementary students. International Journal on New Trends in Education and Their Implications, 3(4), 79-91.

Yılmaz, M. \& Benli, N. (2010). Sınıf öğretmeni adaylarının okuma alışkanlığına yönelik tutumlarının bazı değişkenlere göre incelenmesi. Erzincan Eğitim Fakültesi Dergisi, 12(1), 281-288.

Yurdakul, B. (2005). Yapılandırmacılık, Demirel, Özcan (Editör), Eğitimde Yeni Yönelimler, (39- 61). Ankara: Pegem A Yayıncilik. 


\title{
OKUDUĞUNU ANLAMAYI YORDAYAN DEĞISTKENLER ÜZERINE BİR ÇALIŞMA
}

\author{
Mustafa BAŞARAN
}

ÖZ

Bu çalışmada, okumaya yönelik tutum, metin türü, metnin konusu, okuma hızı, doğru okuma, ön bilgi eksikliği ve metnin yüzey yapısındaki değişim miktarının, öğrencilerin okuduğunu yüzeysel ve derinlemesine anlama becerileri arasındaki ilişkinin incelenmesi amaçlanmıştır. Araştırmanın çalışma grubu, 2019-2020 eğitim-öğretim y1lı güz döneminde İstanbul ili Esenler ve Zeytinburnu ilçelerinde bulunan resmi ilköğretim okullarına devam eden 4. sinıf öğrencilerinden seçilen 180 öğrencidir. Araştırmada ve öğrencilerin derinlemesine anlama, yüzeysel anlama, okumaya yönelik tutum, öyküleyici metne yönelik tutum, konuya yönelik tutum, doğru okuma, okuma hızı ve metinle ilgili ön bilgi miktarını ölçemeye yönelik araştırmacı tarafından geliştirilen bir envanter kullanılmıştır. Araştırmada yapılan regresyon analizi sonuçlarına göre metni derinlemesine anlamayı yordayan değişkenlerin göreli önem sırası, yüzeysel anlam kurma, okumaya yönelik tutum, metnin yüzeysel yapısı, konuya yönelik tutum, doğru okuma, öyküleyici metne yönelik tutum, okuma hızı ve ön bilgiler şeklindedir. Bu faktörler birlikte, derinlemesine anlam kurmanın \% 42'sini açıklamaktadır. Yüzeysel anlam kurmayı yordayan değişkenlerin göreceli önem sırası derinlemesine anlama, metnin yüzeysel yapısındaki değişim, okumaya yönelik tutum, doğru okuma, ön bilgiler, öyküleyici metne yönelik tutum, konuya yönelik tutum ve okuma hızıdır. Bu faktörler birlikte, yüzeysel anlam kurmanın \% 33'ünü açıklamaktadır.

Anahtar Kelimeler: okuduğunu anlama, okuma tutumu, metin yapısı, okuma hızı, ön bilgi 